\title{
AMMONIA LEACHING RESEARCH OF EAF DUSTS AFTER WEALZ-PROCESS
}

\author{
Yulia TOPORKOVA, Sergey MAMYACHENKOV, Olga ANISIMOVA, Daria PRODANOVA \\ Ural Federal University named after the First President of Russia B. N. Yeltsin, Yekaterinburg, \\ Russian Federation, iulia.toporkova@gmail.com
}

https://doi.org/10.37904/metal.2019.756

\begin{abstract}
An efficient technology is currently being searched for the processing of electric arc furnace (EAF) steelmaking dust obtained at the Ural steelmaking plants. In this study, the hydrometallurgical processing of electric arc furnace dusts after Wealz process was investigated on a laboratory scale under normal temperature and pressure conditions. The Waelz-fume is the following chemical composition: $61 \mathrm{wt} \% \mathrm{Zn}, 10 \mathrm{wt} \% \mathrm{Cl}, 6 \mathrm{wt} \% \mathrm{~Pb}$, $1 \mathrm{wt} \% \mathrm{Fe}, 1 \mathrm{wt} \% \mathrm{~K}$. The most optimal for hydrometallurgical processing are ammonia solutions, which allow to transfer zinc into the solution while lead and iron ought to remain as a solid residue. During the process complicated chemical reactions proceed with the zinc complex compounds formation resulting from the interaction between $\mathrm{Zn}^{2+}, \mathrm{Cl}^{-}$ions and $\mathrm{NH}_{3}$ ligands depending on the $\mathrm{pH}$ value. Therefore, this method does not require the introduction of additional purification stages from chlorine and fluorine ions, which make processing difficult, since their accumulation can lead to difficulty in stripping cathode zinc.

The zinc behavior under the influence of ammonium chloride with ammonium as the leaching agents was discussed. Based on the obtained data plots were built and the dependence between the ratio liquid-solid (L/S), ammonium chloride and ammonium concentration were investigated. Optimal leaching parameters were determined. The possibility of zinc electroextraction from the ammonium solutions with obtained cathode zinc was studied.
\end{abstract}

Keywords: EAFD, ammonia, leaching, zinc, electroextraction

\section{INTRODUCTION}

Electric arc furnace dust (EAFD) can be considered as such a source for metallic zinc processing. During scrap and iron smelting with direct reduction, in an electric arc furnace 10-30 $\mathrm{kg}$ of EAFD are produced per one ton of liquid steel; thus 650,000 tons of EAF dusts are generated annually in Russia.

The main reasons for the zinc formation in dust are the mechanical removal of melt droplets and the distillation of metals having a relatively low boiling point [1]. The zinc in EAFD is the second place after iron; its content can reach $15-40 \%$. In addition, in EAF dust contain lead, cadmium, copper, calcium, potassium, chlorine and fluorine [2]. Since even a small content of non-ferrous metals significantly reduces the steel structures quality, this dust cannot be returned to the ferrous metallurgy. The EAFD chemical composition is quite complex and varied, that depends on the technology used and on the feedstock composition. A significant part of zinc is in the form of a stable compound $\left(\mathrm{ZnFe}_{2} \mathrm{O}_{4}\right)$, which is insoluble without both the elevated temperatures and solvent high concentrations using [3].

Various pyrometallurgical, hydrometallurgical and combined technologies have been developed for EAF dust processing. Pyrometallurgical technologies [4-6] are consisted of the high-temperature zinc oxide reduction by various reagents with subsequent zinc vapor distillation in the different furnace structure, for example Waelz process, sintering, FASTMET and FASTMELT, OXYCUP, ZincOx, Primus, ArcFume.

The Waelz process is a classic method for processing $90 \%$ metallurgical dust containing zinc and lead. The final products are iron residue, which are probably suitable for return to ferrous metallurgy, and pure zinc oxide as a final product. However, metallic zinc is possible to obtain by hydrometallurgical processing. 
Hydrometallurgical methods are based on the transfer of a valuable component into a solution in the various form [7], and waste materials remains in the separated cake. Such processes are more flexible, allow to processing dust with a constantly changing composition and a low content of valuable components. Methods can be divided according to the type of solvent used - acidic, alkaline, complexing.

EAFD leaching with using acids, such as sulfuric, acetic, nitric, hydrochloric and their mixture, are known. Sulfuric acid is one of the most common solvents in zinc hydrometallurgy [8]. However, iron passes into the solution along with zinc and additional purification steps is required. Caustic soda, lime, and ammonia are the most common alkaline reagents. The authors [9] considered more selective for zinc is alkaline leaching, with using caustic soda, because iron does not dissolve in alkalis. Thus, the predominant components are contained in the alkaline solutions after leaching are zinc and lead, which can be easily separated. Metallic zinc can be obtained from sulphate and alkaline solutions by the electrochemical method.

Ammonium chloride is an attractive lixiviant in hydrometallurgy and is commonly used for the extraction of zinc, nickel, and copper, since these metals form stable metal ammine complexes [10]. The advantages of ammonia leaching are low toxicity, low cost, and ease of regeneration. Complexing ligands including ammonia attach to metal ions through a reactive nitrogen-containing group to form strong metal complexes. Moreover, such metals as iron and calcium in EAFD exhibit poor complexation ability with ammonia and are insoluble in solutions.

In this paper a hydrometallurgical method of EAFD processing combined with the Waelz process was investigated. At the first stage, a high-heat treatment of the raw material was conducted at the Waelz kiln, in order to destroy stable zinc ferrite and transfer zinc to the soluble oxide phase. Then formed zinc oxide was leached in ammonia-ammonium chloride media according to Equation (1)

$\mathrm{ZnO}+2 \mathrm{NH}_{4} \mathrm{Cl}+4 \mathrm{NH}_{3}+\mathrm{H}_{2} \mathrm{O}=\left[\mathrm{Zn}\left(\mathrm{NH}_{3}\right)_{4}\right] \mathrm{Cl}_{2}+2 \mathrm{NH}_{4} \mathrm{OH}$

Then zinc extraction from the solution by electrochemical method to obtain high-purity compact zinc as the final product was conducted. Equation (2) represents total reaction on the bath at the electroextraction.

$3\left[\mathrm{Zn}\left(\mathrm{NH}_{3}\right)_{4}\right] \mathrm{Cl}_{2}+2 \mathrm{NH}_{4} \mathrm{OH}=3 \mathrm{Zn}+\mathrm{N}_{2}+2 \mathrm{H}_{2} \mathrm{O}+6 \mathrm{NH}_{4} \mathrm{Cl}$

\section{MATERIALS AND METHODS}

\subsection{Materials characterization}

Electric arc furnace dust after the Waelz process was used to investigate zinc extraction in dependence of leaching regimes. The dust samples originated from one of the Ural steel-producing plant.

Preliminary thermal processing of dust was performed in the Waelz furnace at temperature $1100{ }^{\circ} \mathrm{C}$ with coke as reducing agent. The Waelz slag, in which iron was concentrated, was returned in the ferrous processing. The Waelz dust was cooled down and analyzed for further research.

The mineralogical characterization of dust was carried out using X-ray diffraction method. The chemical composition of dust was carried out using ICP-EMS method combined with total dissolving of the sample. Leaching solutions analysis was carried out using atomic absorption methods. Chemical and mineral characterizations of dust are shown in Table 1 and Figure 1 respectively.

Table 1 Chemical composition of the EAFD after the Waelz process (wt\%)

\begin{tabular}{|c|c|c|c|c|c|}
\hline $\mathbf{Z n}$ & $\mathbf{C l}$ & $\mathbf{P b}$ & $\mathbf{C a}$ & $\mathbf{K}$ & $\mathbf{F e}$ \\
\hline 61 & 10 & 6 & 4 & 4 & 1 \\
\hline
\end{tabular}




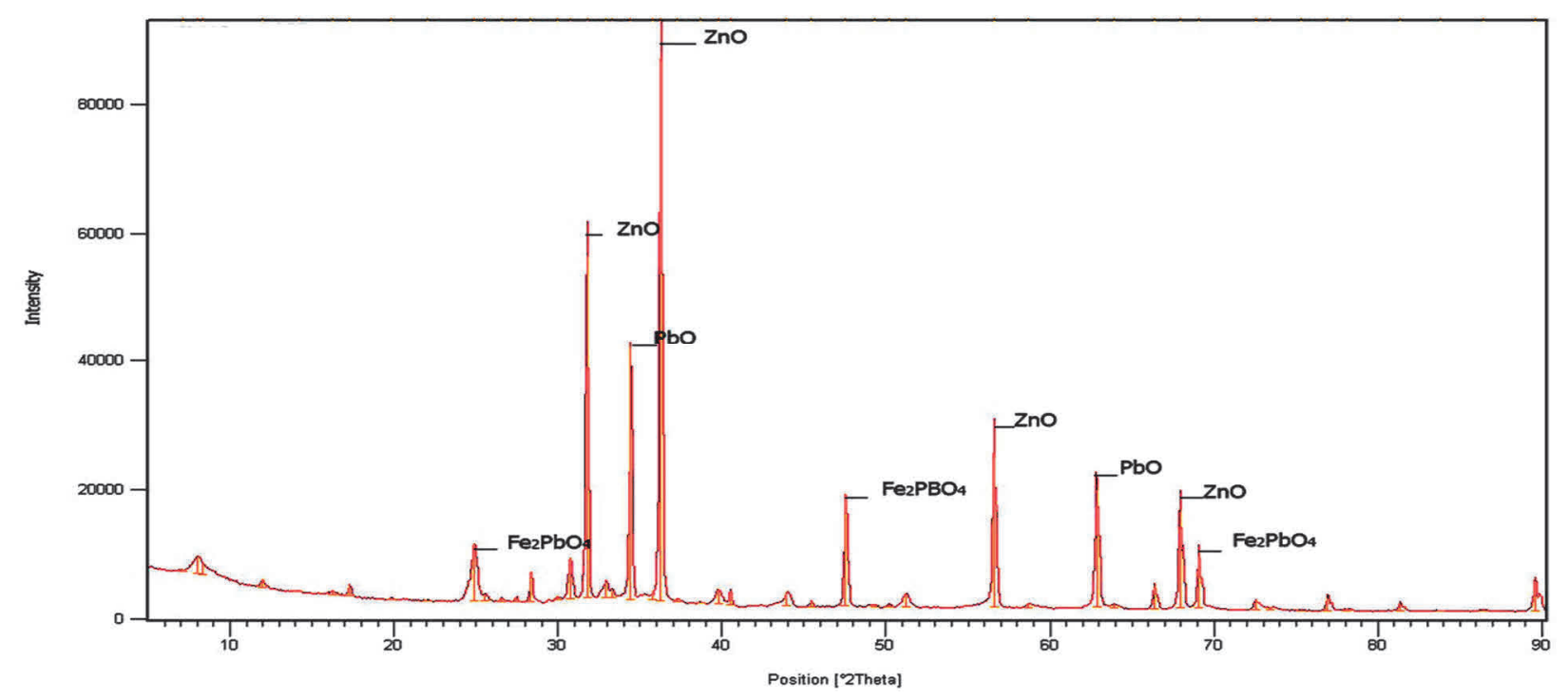

Figure $1 \mathrm{X}$-ray diffraction spectrum of the EAFD after the Waelz process

\subsection{Experimental methods}

The experiments on leaching of dust after the Waelz process were performed in a glass vessel without air access in ammonia-ammonium chloride solution at ambient temperature with different duration, $\mathrm{NH}_{3}\left(2-{ }_{4}\right.$ $\mathrm{mol}), \mathrm{NH}_{4} \mathrm{Cl}$ (2-4 mol) concentration, and liquid to solid ratio (L/S). Mineral characterization of the solid residue after ammonium leaching is shown in Figure 2.

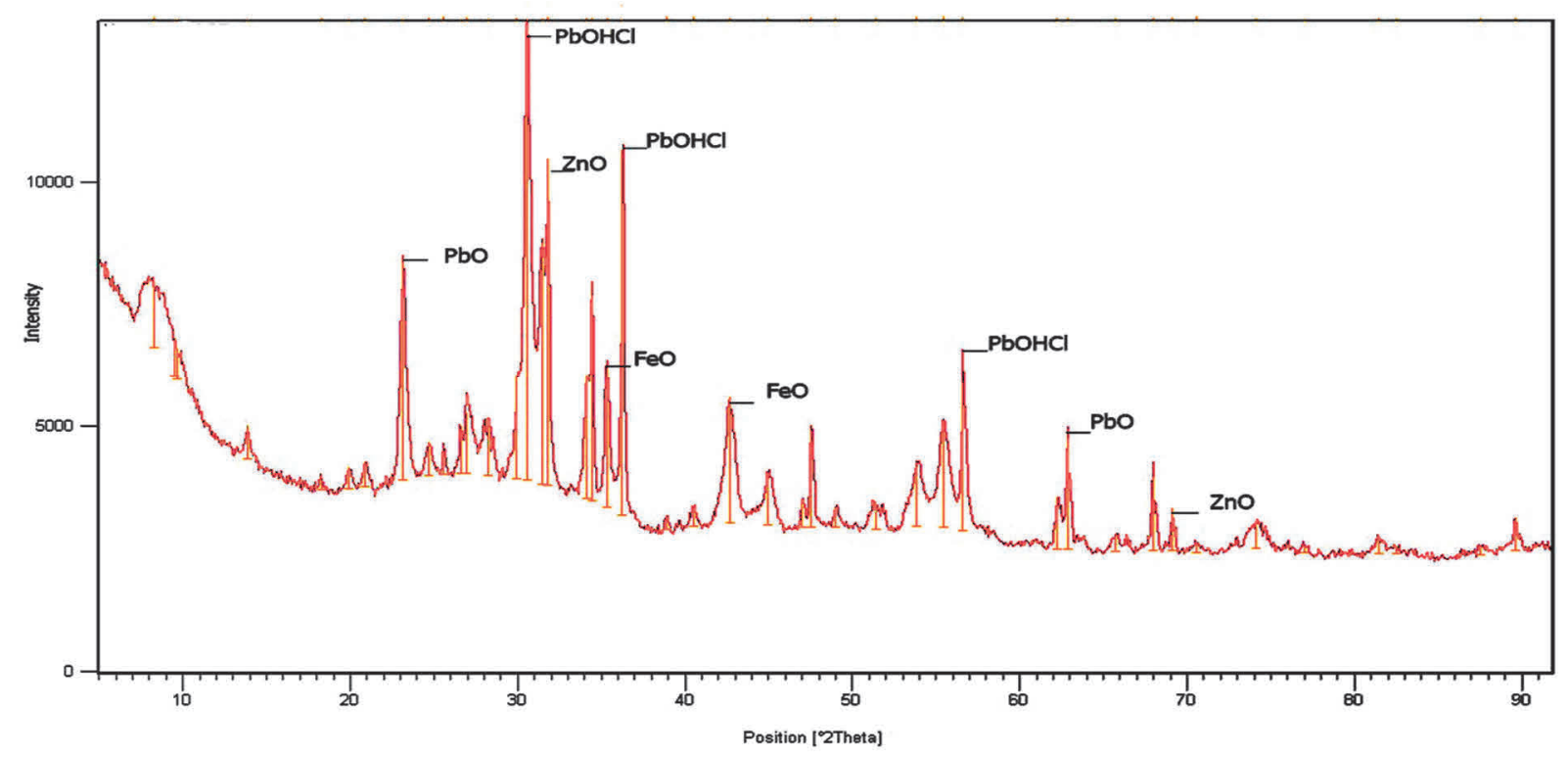

Figure 2 X-ray diffraction spectrum of the EAFD after the Waelz process

The experiments of electroextraction were conducted in a polythene cell with stripped, the distance between the anode and cathode was fixed at $3 \mathrm{~cm}$. The electroextraction was realized with a titanium cathode and a graphite anode at the current density $300 \mathrm{~A} / \mathrm{m}^{2}$.Electrolyte was obtained after ammonia-ammonium chloride leaching at the optimal parameters. The initial zinc concentration in the electrolyte was $50 \mathrm{~g} / \mathrm{dm}^{3}$. The cathodic zinc was stripped every 3 hours and analyzed X-ray fluorescence analysis. 


\section{RESULTS AND DISCUSSION}

\subsection{Effect of duration}

The first tests were carried out to determine the optimal duration of leaching process. The studies were conducted with a change in the duration from 10 to 60 minutes at higher concentration of $\mathrm{NH}_{3}=4 \mathrm{~mol}, \mathrm{NH}_{4} \mathrm{Cl}$ $=4 \mathrm{~mol}$ and the L/S ratio of 20. The results are shown in Figure 3. As shown in figure, main part of zinc goes into solution during 10 minutes, and then dissolution rate decreased. Thus, the optimal time for leaching was taken as 40 minutes, probably due to with ammonia consumption for reactions.

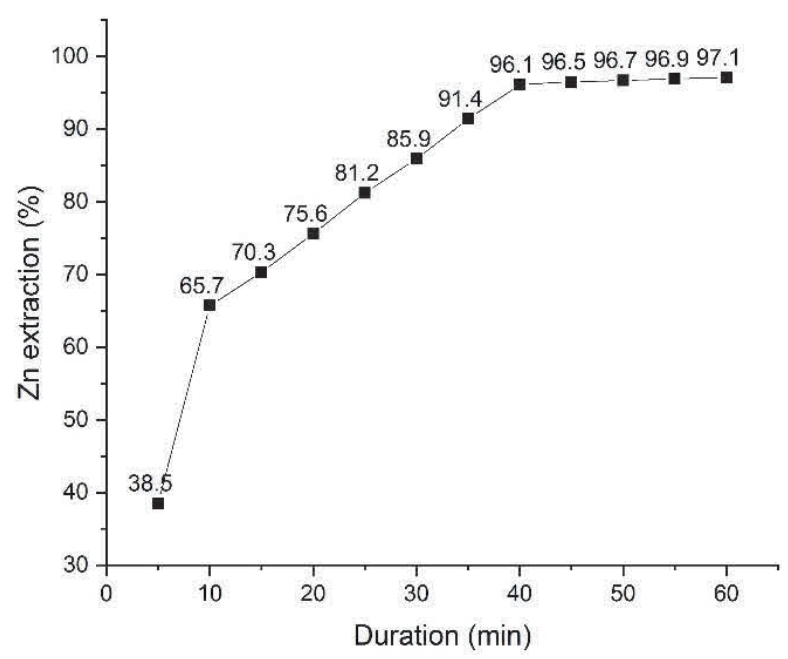

Figure 3 Extraction of zinc as a function of duration at $4 \mathrm{M} \mathrm{NH}_{4} \mathrm{Cl}, 4 \mathrm{M} \mathrm{NH} 3$, $\mathrm{L} / \mathrm{S}=20$

\subsection{Effect of total ammonia concentration}

The next series of experiments was performed for seeking the optimal total ammonia $\left(\mathrm{NH}_{3}\right.$ and $\left.\mathrm{NH}_{4}{ }^{+}\right)$ concentration of leaching process. The studies were carried out with a change from 2 to 8 mol during 40 minutes at L/S ratio of 10,15, 20. The results are shown in Figure 4. As shown in figure, a significant increase in $\mathrm{Zn}$ extraction and influence of L/S can be observed at total ammonia concentration from 2 to $6 \mathrm{~mol}$. At a concentration above $6 \mathrm{~mol}$ zinc extraction remained constant, the effected L/S on the leaching stopped. Thus, the optimal total ammonia concentration for leaching was taken as $6 \mathrm{~mol}$ and L/S as 15 .

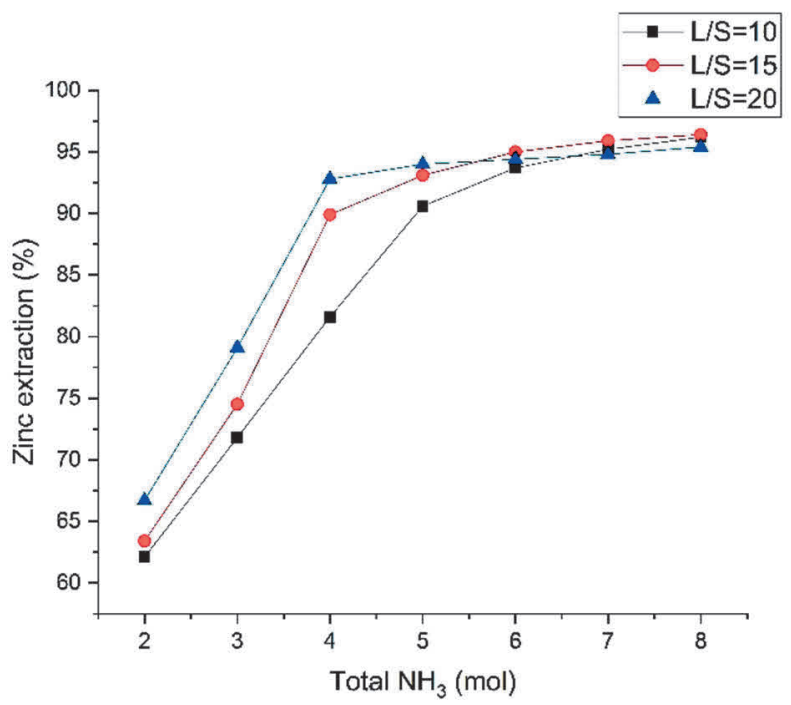

Figure 4 Extraction of zinc as a function of total ammonia concentration at L/S $=10,15,20$ 


\subsection{Effect of $\mathrm{NH}_{3}$ and $\mathrm{NH}_{4} \mathrm{Cl}$ concentration}

The last series of experiments was performed for seeking the optimal concentration of $\mathrm{NH}_{3}\left(\mathrm{C}_{\mathrm{NH}}\right)$ and $\mathrm{NH}_{4} \mathrm{Cl}$ $\left(\mathrm{C}_{\mathrm{NH} 4 \mathrm{CI}}\right)$ at the $\mathrm{L} / \mathrm{S}=15$. The results are shown in Figure 5 . The leaching process was investigated in a range of L/S ratio from 10 to $20, \mathrm{C}_{\mathrm{NH} 3}$ and $\mathrm{C}_{\mathrm{NH} 4 \mathrm{Cl}}$ from 2 to $4 \mathrm{~mol}$ for 40 minutes at ambient temperature. Surface plot were constructed and equation for it was compiled based on the obtained data using the program Statistica to established optimal parameters. The maximum extraction of $97 \%$ was achieved at the $\mathrm{C}_{\mathrm{NH} 4 \mathrm{Cl}}$ and $\mathrm{C}_{\mathrm{NH}}$ of 4 mol. In order to optimize the process 3 mol for $\mathrm{C}_{\mathrm{NH} 4 \mathrm{Cl}}$ and $\mathrm{C}_{\mathrm{NH} 3}$ was taken.

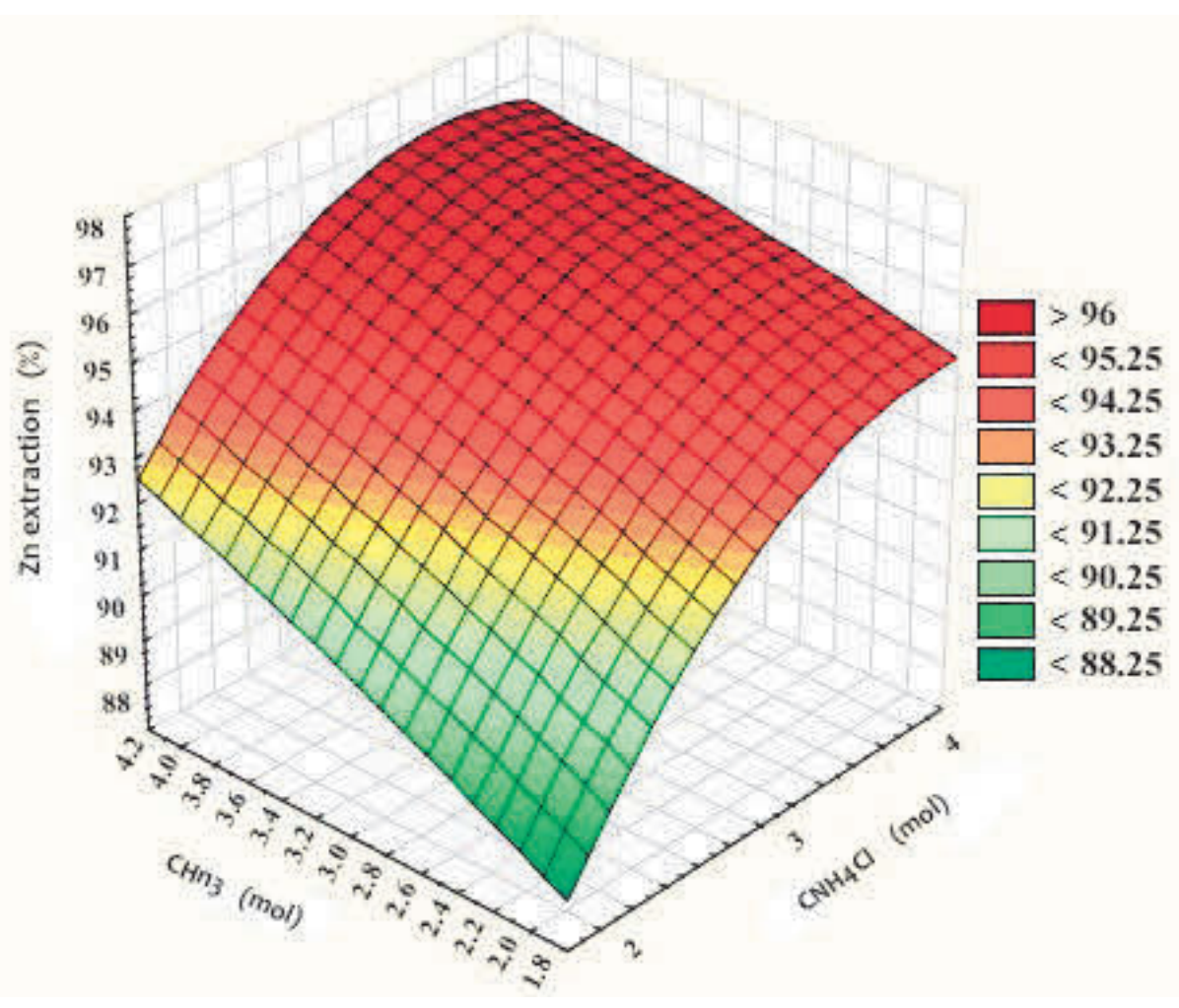

Figure 5 Extraction of zinc as a function of $\mathrm{NH}_{3}$ and $\mathrm{NH}_{4} \mathrm{Cl}$ concentration, $\mathrm{L} / \mathrm{S}=15$

$Y\left(X_{1} ; X_{2}\right)=67.6583+11.1083 X_{1}+3.60833 X_{2}-0.475 X_{1} X_{2}-1.25 X_{1}^{2}-0.15 X_{2}^{2}$

where $Y\left(X_{1} ; X_{2}\right)$ - zinc extraction;

$\mathrm{X}_{1}-\mathrm{NH}_{4} \mathrm{Cl}$ concentration;

$\mathrm{X}_{2}-\mathrm{NH}_{3}$ concentration.

The Equation (3) describes the surface plot, which allows assessing the influence of the $\mathrm{NH}_{3}$ and $\mathrm{NH}_{4} \mathrm{Cl}$ concentration on the zinc extraction. The equation coefficients at the $\mathrm{X}_{1}$ and $\mathrm{X}_{2}$ are positive, and then both $\mathrm{NH}_{3}$ and $\mathrm{NH}_{4} \mathrm{Cl}$ concentration were affected on the zinc extraction. The coefficient at $\mathrm{X}_{1}$ is higher, which means $\mathrm{C}_{\mathrm{NH} 4 \mathrm{Cl}}$ influence is greater.

\subsection{Zinc electroextraction}

Zinc electroextraction was conducted from solution after leaching at the optimal parameters with the initial content of $\mathrm{Zn}$ was $50 \mathrm{~g} / \mathrm{dm}^{3}$. Preliminary solution was cleaned of lead by cementation on zinc powder. The voltage on the bath was measured every 20 minutes, average voltage was $2.6 \mathrm{~V}$. Current efficiency was $97 \%$, zinc purity was $99.98 \%$. Chlorine gas was not emission at the anode, due to the rapid interaction of active 
atomic chlorine and ammonia, leading to the state oxidation balancing and the formation of inert gaseous nitrogen.

\section{CONCLUSION}

A hydrometallurgical method of EAFD processing comprising the Waelz process with followed by ammoniaammonium chloride leaching was investigated. The optimal parameters for the leaching process were the following: $\mathrm{NH}_{3}$ concentration $3 \mathrm{~mol}, \mathrm{NH}_{4} \mathrm{Cl}$ concentration $3 \mathrm{~mol}$ and $\mathrm{L} / \mathrm{S}$ ratio 15 . $\mathrm{Zn}$ extraction in the leaching process of dusts after the Waelz process with such parameters was reached $95.5 \%$ and metallic zinc with a purity of $99.98 \%$ was deposited from solution after leaching.

\section{REFERENCES}

[1] DAS, Bibhuti B., READDY, P.S.R., PRAKASH, Subramanian and MISRA, Vibnuti N. An overview of utilization of slag from steel industries. Resource, Conservation \& Recycling. 2007. no. 1, pp. 40-57.

[2] MACHADO, Janaina G.M.S., BREHM, Feliciane A., MORAES, Carlos A.M., SANTOS, Carlos. A., VILELA, Antonio.C.F. and CUNHA, Joao B.M. Chemical, physical, structural and morphological characterization of the electric arc furnace dust. Journal of Hazardous Material. 2006. vol. 136, no. 3, pp. 953-960.

[3] PENG, Hailong L. Study on the behavior of zinc ferrite in conventional hydrometallurgical zinc production process. Hunan Nonferrous Metals. 2004. no. 5, pp. 20-29.

[4] MCCLELLAND, James M. and METIUS Gary E. Recycling Ferrous and Nonferrouse Waste Streams with FASTMET. Journal of the Minerals, Metals and Materials Society. 2003. no. 8. pp, 30-34.

[5] MORCALI, Mehmet H., YUCEL, Onuralp, AYDIN, Ahmed and DERIN, Bora. Carbothermic reduction of electric arc furnace dust and calcination of waelz oxide by semi-pilot scale rotary furnace. Journal of Mining and Metallurgy. 2012. vol. 48, no. 2, pp, 173-184.

[6] XIAOLONG, Lin, ZHIWEI, Peng, JIAXING, Yan, ZHIZHONG, Li, JIANN_YANG, Hwang, YUANBO, Zhang, GUANGHUI, Li and TAO, Jiang. Pyrometallurgical recycling of electric arc furnace dust. Journal of Cleaner Production. 2017. vol. 149, no. 1, pp, 1079-1100.

[7] SEBAGA, M. G., KORZENOWSKIA, C., BERNARDESA, A. M. and VILELA, A. C. Evaluation of environmental compatibility of EAFD using different leaching standards. Journal of Hazardous Materials. 2009. vol. 166, no. 2-3, pp. 670-675.

[8] OUSTADAKIS, Paschalis, TSAKIRIDIS, Petros E., KATSIAPI, A. and AGATZINI-LEONARDO, Styliani. Hydrometallurgical process for zinc recovery from electric arc furnace dust (EAFD). Part I: Characterization and leaching by diluted sulphuric acid. Journal of Hazardous Materials. 2010. vol. 179, no. 1-3, pp. 1-7.

[9] AL-MAKHADMEH, Leema A., BATIHA, Mohammad A., AL-HARAHSHEH, Mohammad S. and ALTARAWNEH, Ibrahem S. The effectiveness of Zn Leaching from EAFD using caustic soda. Water Air Soil Pollut. 2018. vol. 33, no. 2, pp. 4-10.

[10] OLPER, M. and MACCAGNI, M. From C.Z.O. to zinc cathode without any pretreatment. The EZINEX process, Lead and Zinc. 2008. no. 1, pp. 85-98. 